Research Paper

\title{
Extracellular polysaccharide production by a strain of Pleurotus djamor isolated in the south of Brazil and antitumor activity on Sarcoma 180
}

\author{
Gisele Martini Borges ${ }^{1}$, Fabiana Figueredo Molin De Barba ${ }^{1}$, Ana Paula Schiebelbein ${ }^{2}$, \\ Bruna Parmezzani Pereira ${ }^{3}$, Mariane Bonatti Chaves ${ }^{4}$, Marcia Luciane Lange Silveira ${ }^{3}$, \\ Mauro Souza Leite Pinho ${ }^{1}$, Sandra Aparecida Furlan ${ }^{1,2,4,5}$, Elisabeth Wisbeck ${ }^{2,4,5}$ \\ ${ }^{1}$ Mestrado em Saúde e Meio Ambiente, Universidade da Região de Joinville, Univille, \\ Joinville, SC, Brazil. \\ ${ }^{2}$ Departamento de Engenharia Ambiental, Universidade da Região de Joinville, Univille, \\ Joinville, SC, Brazil. \\ ${ }^{3}$ Departamento de Farmácia, Universidade da Região de Joinville, Univille, Joinville, SC, Brazil. \\ ${ }^{4}$ Departamento de Engenharia Química, Universidade da Região de Joinville, Univille, \\ Joinville, SC, Brazil. \\ ${ }^{5}$ Mestrado em Engenharia de Processos, Universidade da Região de Joinville, Univille, \\ Joinville, SC, Brazil.
}

Submitted: September 21, 2011; Approved: April 4, 2013.

\begin{abstract}
Polysaccharides with medicinal properties can be obtained from fruiting bodies, mycelium and culture broth of several fungus species. This work was carried out in batch culture using a stirred tank reactor with two different initial glucose concentrations (40-50 g/L) and pH values (3.0-4.0) to enhance extracellular polysaccharides production by Pleurotus djamor UNIVILLE 001 and evaluate antitumor effect of intraperitonial administration of Pleurotus djamor extract on sarcoma 180 animal model. According to factorial design, the low $\mathrm{pH}$ value ( $\mathrm{pH} 3.0$ ) led to a gain of $1.6 \mathrm{~g} / \mathrm{L}$ on the extracellular polysaccharide concentration, while glucose concentration in the tested range had no significant effect on the concentration of polysaccharide. With $40 \mathrm{~g} / \mathrm{L}$ initial glucose concentration and $\mathrm{pH} \mathrm{3.0,} \mathrm{it} \mathrm{was} \mathrm{observed} \mathrm{that} \mathrm{yield} \mathrm{factor} \mathrm{of} \mathrm{extracellular} \mathrm{polysaccharide} \mathrm{on} \mathrm{substrate}$ $\left(\mathrm{Y}_{\mathrm{P} / \mathrm{S}}=0.072\right)$ and maximum extracellular polysaccharide productivity $\left(\mathrm{Q}_{\mathrm{P} \max }=11.26 \mathrm{mg} / \mathrm{L} . \mathrm{h}\right)$ were about $188 \%$ and $321 \%$ respectively higher than those obtained in the experiment performed at $\mathrm{pH}$ 4.0. Under these conditions, the highest values of the yield factor of biomass on substrate $\left(\mathrm{Y}_{\mathrm{X} / \mathrm{S}}=0.24\right)$ and maximal biomass productivity $\left(\mathrm{Q}_{\mathrm{X} \max }=32.2 \mathrm{mg} / \mathrm{L} . \mathrm{h}\right)$ were also reached. In tumor response study, mean tumor volume on the 21th day was $35.3 \mathrm{~cm}^{3}$ in untreated group and $1.6 \mathrm{~cm}^{3}$ in treated group $(\mathrm{p}=0.05)$ with a tumor inhibition rate of $94 \%$. These impressive results suggests an inhibitory effect of P.djamor extract on cancer cells.
\end{abstract}

Key words: Pleurotus djamor, extracellular polysaccharides production, antitumor activity.

\section{Introduction}

Natural products have been traditionally accepted as solutions to health, due to popular beliefs that they have fewer adverse effects (Mantovani et al., 2008). Edible fungi have been widely used as functional foods and their extracts have been studied in natural therapy for prevention and treat- ment of tumors, raising commercial interest (Firenzuoli et al., 2008). Pleurotus sp. antitumor activity has been focused by several studies (Zhang et al., 2004; Gu and Sivam, 2006; Lavi et al., 2006; Sarangi et al., 2006; Jedinak and Sliva, 2008; Wolff et al., 2008; Dalonso et al., 2010).

The culture medium and conditions must be related to the nutritional needs of the microorganism and strongly in-

Send correspondence to E. Wisbeck. Master Program in Process Engineering, Department of Chemical Engineering and Department of Environmental Engineering. University of the Region of Joinville, 89.219-710 Joinville, SC, Brazil. E-mail: ewisbeck@univille.br. 
fluence the metabolite formation, such as the intracellular polysaccharides (Shih et al., 2006), the extracellular polysaccharides (Hwang et al., 2003; Wisbeck, 2003; Gern et al., 2008; Shih et al., 2008; Furlan et al., 2009), and the biomass formation (Hwang et al., 2003; Wisbeck, 2003; Cho et al., 2006; Shih et al., 2008).

Several research groups have been developing experiments in shake flasks or bioreactors using different fungi species in order to optimize the production of polysaccharides by varying the concentration of nutrient sources and the growing conditions such as $\mathrm{pH}$, temperature and aeration (Hwang et al., 2003; Cho et al., 2006; Shih et al., 2006; Furlan et al., 2008; Gern et al., 2008; Shih et al., 2008).

However, informations about nutritional requirements and environmental conditions for submerged culture of Pleurotus djamor are still limited. In the present study the biomass and extracellular polysaccharide production by P. djamor was evaluated in batch culture, using a stirred tank reactor. The influence of initial glucose concentration and $\mathrm{pH}$ control on mycelial growth and polysaccharide production were demonstrated. Inhibitory effect of P.djamor extract on cancer cells was proven.

\section{Materials and Methods}

\section{Microorganisms and inoculum preparation}

$P$. djamor UNIVILLE 001, isolated in the garden of the University of the Region of Joinville - UNIVILLE, was maintained in Petri dishes at $4{ }^{\circ} \mathrm{C}$ on WDA (Wheat Dextrose Agar) medium (Furlan et al., 1997). The inoculum was prepared in a $2 \mathrm{~L}$ Duran flask containing $400 \mathrm{~mL}$ of POL medium: $\left(\mathrm{NH}_{4}\right)_{2} \mathrm{SO}_{4} 5.0 \mathrm{~g} ; \mathrm{MgSO}_{4} .7 \mathrm{H}_{2} \mathrm{O} 0.2 \mathrm{~g}$; $\mathrm{K}_{2} \mathrm{HPO}_{4} 1.0 \mathrm{~g}$; yeast extract $2.0 \mathrm{~g}$; peptone $1.0 \mathrm{~g} ; \mathrm{CaCO}_{3}$ $1.0 \mathrm{~g}$; glucose $20 \mathrm{~g}$ in $1 \mathrm{~L}$ of distilled water (Cavazzoni and Adami, 1992). $\mathrm{pH}$ value was 6.5 - 7.0, and the medium was sterilized at $15 \mathrm{psi}$ and $121{ }^{\circ} \mathrm{C}$. The entire content of one Petri dish was used to inoculate each Duran flask. The flasks were incubated at $30{ }^{\circ} \mathrm{C}$ on a rotary shaker at $120 \mathrm{rpm}$, for six days (Wisbeck, 2003).

\section{Extracellular polysaccharides and biomass production}

A factorial design $2^{2}$ was used to evaluate the influence of initial glucose concentration (40 and $50 \mathrm{~g} / \mathrm{L}$ ) and $\mathrm{pH}$ control (3.0 and 4.0) on biomass $(\mathrm{X})$ and extracellular polysaccharide $(\mathrm{P})$ production in batch cultivation. These conditions were selected based on the results obtained by Wisbeck (2003) showing that $P$. ostreatus accumulated higher concentrations of extracellular polysaccharides with $40 \mathrm{~g} / \mathrm{L}$ glucose and initial $\mathrm{pH} 4$.

Culture medium composition was similar to that described in 2.1, except for glucose concentration (40 and $50 \mathrm{~g} / \mathrm{L}$ ). The medium was sterilized and inoculated with an inoculation ratio equal to $10 \%(\mathrm{v} / \mathrm{v})$ and cultivated in a $5 \mathrm{~L}$ stirred tank reactor (Biostat B, B. BRAUN, Germany) with $4 \mathrm{~L}$ working volume. The cultivation was performed under the following conditions: $30^{\circ} \mathrm{C}, 0.25 \mathrm{~L} / \mathrm{min}$ air flow and $300 \mathrm{rpm}$ (initial $\mathrm{K}_{\mathrm{L}}$ a equal to $15 \mathrm{l} / \mathrm{h}$ ) and $\mathrm{pH} 3.0$ or $4.0 \mathrm{ac}$ cording to the experiment.

All experiments were performed in duplicate and the calculation of the kinetic parameters was based on the kinetic profiles, using the data of both replications.

For the statistic analysis of the factorial design, the Paretos method was used (Barros Neto et al., 1996).

The culture broth was filtered, washed with distilled water and the retained biomass was dried at $60^{\circ} \mathrm{C}$ for $48 \mathrm{~h}$ for the determination of the biomass dry weight.

The glucose concentration was determinated by the Enzyme-Glucose Test (Wiener Laboratórios, Brasil).

After biomass separation, $10 \mathrm{~mL}$ of the broth were treated with acetone cooled to $8{ }^{\circ} \mathrm{C}(3: 1, \mathrm{v} / \mathrm{v})$ (Rosado et al., 2003), and maintained for $24 \mathrm{~h}$ under refrigeration $\left(4{ }^{\circ} \mathrm{C}\right)$ for extracellular polysaccharide precipitation. The precipitate was centrifuged at $3373 \mathrm{~g}$ for $5 \mathrm{~min}$. The supernatant was separated and the precipitate was washed twice, using an acetone:ethanol:distilled water solution $(3: 1: 1, \mathrm{v} / \mathrm{v} / \mathrm{v})($ Cavazzoni and Adami, 1992). The extracellular polysaccharide concentration was estimated in the precipitate by the phenol-sulfuric method (Dubois et al., 1956).

\section{Polysaccharides extracts}

Extracellular polysaccharides were produced in Pleurotus djamor submerged culture in POL medium (section 2.2) with $40 \mathrm{~g} / \mathrm{L}$ initial glucose and $\mathrm{pH}$ 3.0. Extraction (Pokhrel and Ohga, 2007) in which ethanol PA (4:1, v/v) was added to the culture broth and left for 24 hours at $4{ }^{\circ} \mathrm{C}$, with the formed precipitate being separated by centrifugation and lyophilized. The obtained material was prepared in concentration of $10 \mathrm{~g} / \mathrm{L}$ for $30 \mathrm{mg} / \mathrm{kg}$ doses in phosphate buffered saline solution (PBS $0.01 \mathrm{M}, \mathrm{pH}$ 7.0). These parameters were established from a previous study comparing different methods of extraction, concentration and doses to determine the optimal antitumor effect.

\section{Animal study}

These were performed after following the protocol by the Ethics Committee of University of the Region of Joinville (No. 031/2008) and were carried out in accordance with current guidelines for the Care and Use of Laboratory Animals - Commission on Life Sciences, National Research Council, 1996.

Swiss albino mice were housed under standard conditions of temperature $\left(21 \pm 2{ }^{\circ} \mathrm{C}\right)$, relative humidity $(60 \pm 10 \%)$ and $12 \mathrm{~h} \mathrm{light} / 12 \mathrm{~h}$ dark cycle at the Cronic Treatment Laboratory. Thirty male Swiss albino mice were divided in two studies, named as Tumor Response Study and Survival Study. 


\section{Tumor response study}

Ten male Swiss albino mice were divided in two groups of five animals each, named Untreated Group (tumor induction with no treatment) and Treated Group (tumor induction with treatment).

Tumor induction and treatment

Sarcoma 180 (S180) tumor culture was obtained by courtesy from the Pharmacology Department from UNIVALI (Itajaí/SC/Brazil), and maintained through weekly intraperitoneal injections in male Swiss albino mice (Pagno et al., 2006). Tumor induction was performed subcutaneously, in the back of each mouse from both Treated and Untreated Groups in a concentration of $25 \times 10^{6} \mathrm{cel} / \mathrm{mL}$, in $0.2 \mathrm{~mL}$ volume (Mizuno et al., 1999).

Polysaccharide extracts were administered intraperitoneally in the Treated Group for ten consecutive days, starting at $24 \mathrm{~h}$ after tumor induction (Zhang et al., 2004), in daily doses of $30 \mathrm{mg} / \mathrm{kg}$ of body weight. A PBS solution was applied intraperitoneally to Untreated Group at a dose of $10 \mathrm{mg} / \mathrm{kg}$.

Assessment of tumor response

Animals were observed from $11^{\text {th }}$ to $20^{\text {th }}$ post-induction days. All mice were sacrificed on the $21^{\text {th }}$ day and tumors were removed. Tumor weight (g) was obtained according to Misaki et al. (1984) and tumor volume $\left(\mathrm{cm}^{3}\right)$ was calculated as proposed by Ajith and Janardhanan (2003) and Lee et al. (2003), through the equation $(4 / 3) \pi\left(\mathrm{a}^{2} \mathrm{~b}\right) / 2$. Inhibition rate was calculated as $[(\mathrm{C}-\mathrm{T}) / \mathrm{C}] * 100$ (Zhang et al., 2004).

\section{Results and Discussion}

\section{Extracellular polysaccharides and biomass production}

The kinetic profiles of glucose $(\mathrm{S})$ consumption, biomass $(\mathrm{X})$ growth and extracellular polysaccharide $(\mathrm{P})$ production, obtained from experiments performed with $40 \mathrm{~g} / \mathrm{L}$ initial glucose and $\mathrm{pH} 3.0,40 \mathrm{~g} / \mathrm{L}$ initial glucose and $\mathrm{pH}$ $4.0,50 \mathrm{~g} / \mathrm{L}$ initial glucose and $\mathrm{pH} 3.0,50 \mathrm{~g} / \mathrm{L}$ initial glucose and $\mathrm{pH} 4.0$, are showed in Figure 1 (A and $\mathrm{B}$ ) and 2 (A and B), respectively.

The time required for glucose consumption by $P$. djamor was lower using $40 \mathrm{~g} / \mathrm{L}$ initial glucose concentration and $\mathrm{pH}$ value 3.0, when compared with the other tested conditions. It can also be observed that independent of the initial glucose concentration, the lower $\mathrm{pH}$ value (3.0) favors glucose consumption.

Table 1 shows the kinetic parameters obtained for the tested conditions. With $40 \mathrm{~g} / \mathrm{L}$ initial glucose concentration, $\mathrm{Y}_{\mathrm{P} / \mathrm{S}}$ and $\mathrm{Q}_{\mathrm{Pmax}}$ obtained in the experiment conducted at $\mathrm{pH} 3.0$ were about $188 \%$ and $321 \%$ higher than those obtained at $\mathrm{pH}$ 4.0. In culture conducted with $50 \mathrm{~g} / \mathrm{L}$ initial glucose concentration, $\mathrm{Y}_{\mathrm{P} / \mathrm{S}}$ and $\mathrm{Q}_{\mathrm{P} \max }$ obtained at $\mathrm{pH} 3.0$
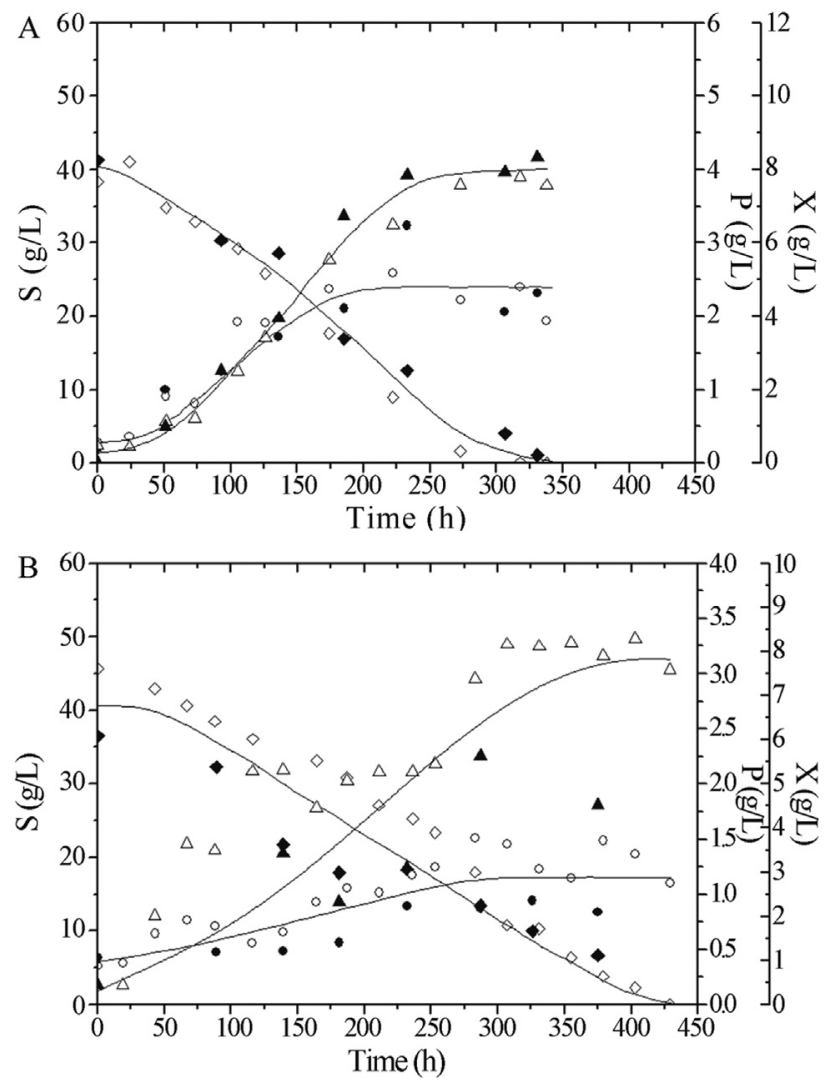

Figure 1 - Kinetics of glucose consumption ( $\diamond \diamond, \diamond)$, biomass growth $(\mathrm{X} \boldsymbol{\Delta}, \Delta)$ and extracellular polysaccharide production $(\mathrm{P}, \mathrm{O}, \mathrm{O})$ for the cultivation of $P$. djamor using $40 \mathrm{~g} / \mathrm{L}$ initial glucose concentration and $\mathrm{pH} 3.0$ (A) and $\mathrm{pH} 4.0$ (B).

were about $190 \%$ and $242 \%$ higher than those obtained at $\mathrm{pH} 4.0$.

Comparing the kinetic parameters obtained at $\mathrm{pH} 3.0$, it can be observed that $40 \mathrm{~g} / \mathrm{L}$ initial glucose concentration promoted the highest yield factor and productivities in polysaccharides $\left(\mathrm{Y}_{\mathrm{P} / \mathrm{S}}=0.072, \mathrm{Q}_{\mathrm{P}}=9.337 \mathrm{mg} / \mathrm{L} . \mathrm{h}\right.$ and $\left.\mathrm{Q}_{\text {Pmax }}=11.260 \mathrm{mg} / \mathrm{L} . \mathrm{h}\right)$.

The initial glucose concentration equal to $40 \mathrm{~g} / \mathrm{L}$ also favored $\mathrm{Q}_{\mathrm{X}}$ and $\mathrm{Q}_{\mathrm{Xmax}}$ independent of the $\mathrm{pH}$ value. Using this initial glucose concentration and $\mathrm{pH} 3.0$, the highest values of $\mathrm{Y}_{\mathrm{X} / \mathrm{S}}$ (0.244), $\mathrm{Q}_{\mathrm{X}}$ (31.4 mg/L.h) and $\mathrm{Q}_{\mathrm{Xmax}}(32.2$ $\mathrm{mg} / \mathrm{L} . \mathrm{h}$ ) were obtained.

Gern et al. (2008) investigated the extracellular polysaccharide production by Pleurotus ostreatus in a stirred tank reactor using $\mathrm{K}_{\mathrm{L}}$ a value equal to $10.21 / \mathrm{h}, \mathrm{pH} 4.0$ and $40 \mathrm{~g} / \mathrm{L}$ initial glucose concentration. The kinetic parameters were: $\mathrm{Y}_{\mathrm{P} / \mathrm{S}}=0.047$ and $\mathrm{Q}_{\mathrm{P}}=7.01 \mathrm{mg} / \mathrm{L}$.h. The values reported by the authors for $\mathrm{Y}_{\mathrm{P} / \mathrm{S}}$ and $\mathrm{Q}_{\mathrm{P}}$ were about 35\% and $25 \%$ lower respectively when compared to the best results obtained in this work (for $\mathrm{S}_{0}=40 \mathrm{~g} / \mathrm{L}$ and $\mathrm{pH}$ 3.0). The authors did not evaluate the behavior of the microorganism in $\mathrm{pH} 3.0$.

Bonatti et al. (2008) studied the production of extracellular polysaccharides by Pleurotus ostreatus in semi- 

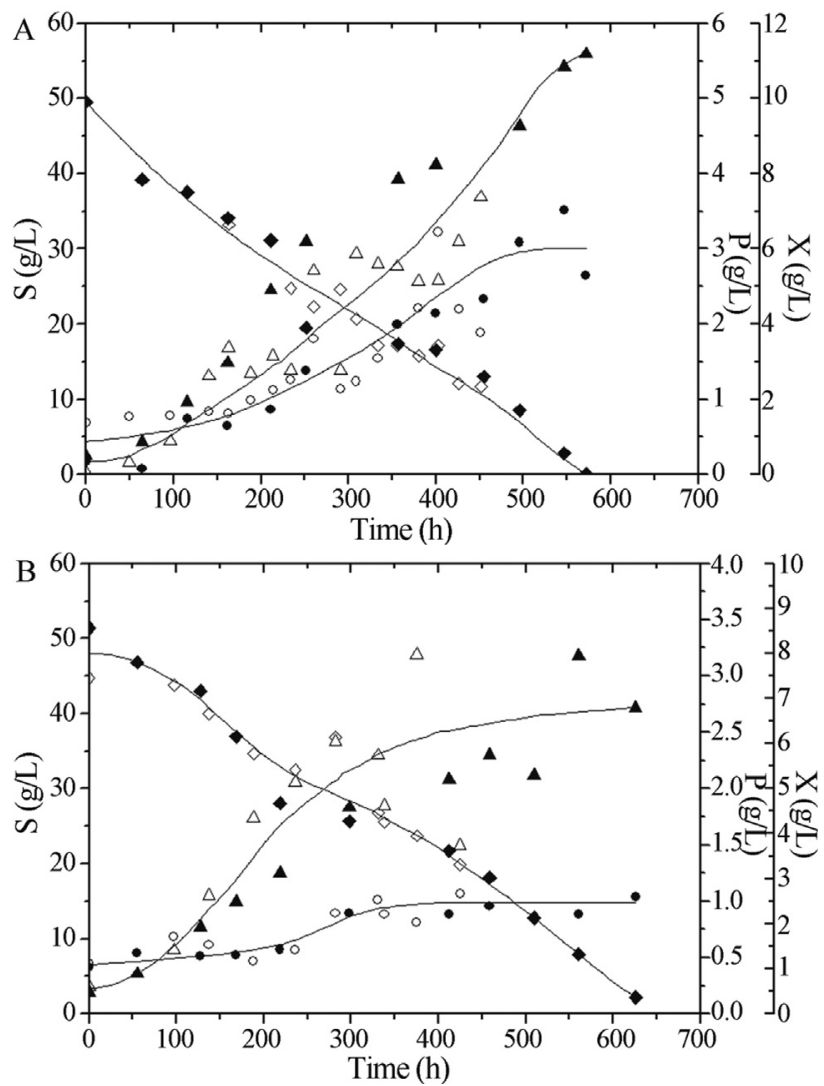

Figure 2 - Kinetics of glucose consumption ( $\mathrm{\diamond}, \diamond)$, biomass growth $(\mathrm{X} \boldsymbol{\Lambda}, \Delta)$ and extracellular polysaccharide production $(\mathrm{P} \boldsymbol{\bullet}, \mathrm{O})$ for the cultivation of $P$. djamor using $50 \mathrm{~g} / \mathrm{L}$ initial glucose concentration and $\mathrm{pH}$ 3.0 (A) and $\mathrm{pH} 4.0$ (B).

continuous process with medium replacements of 50 and $75 \%$ in a bioreactor with $4 \mathrm{~L}$ working volume. $40 \mathrm{~g} / \mathrm{L}$ initial glucose concentration, $\mathrm{pH} 4.0$ and 50\% medium replacement favored the production of polysaccharides $\left(\mathrm{Y}_{\mathrm{P} / \mathrm{S}}=0.09\right.$ and $\left.\mathrm{Q}_{\mathrm{P} \max }=9 \mathrm{mg} / \mathrm{L} . \mathrm{h}\right)$ in the second cycle. Ac- cording to the authors productivity was increased in nearly $30 \%$ compared to batch culture. $\mathrm{Y}_{\mathrm{P} / \mathrm{S}}$ reached by the authors was higher than that obtained in this study (0.072) using $40 \mathrm{~g} / \mathrm{L}$ glucose and $\mathrm{pH}$ 3.0. However, $\mathrm{Q}_{\mathrm{Pmax}}$ reached in this study was about $25 \%$ higher than the value reported by the authors.

Wisbeck (2003) obtained with $P$. ostreatus cultivated in $40 \mathrm{~g} / \mathrm{L}$ initial glucose concentration and $\mathrm{pH}$ 4.0: $\Delta \mathrm{P}=1.32 \mathrm{~g} / \mathrm{L}, \mathrm{Y}_{\mathrm{P} / \mathrm{S}}=0.081$ and $\mathrm{Q}_{\mathrm{P}}=7.50 \mathrm{mg} / \mathrm{L} . \mathrm{h}$. Comparing the data obtained for the same culture conditions ( $40 \mathrm{~g} / \mathrm{L}$ initial glucose concentration and $\mathrm{pH} 4.0$ ) the author reached higher values than those obtained in this work. However, comparing the results reported by the author with those obtained in this study for $\mathrm{pH} 3.0$, the last are higher for $\Delta \mathrm{P}(59 \%)$ and $\mathrm{Q}_{\mathrm{P}}(24 \%)$. The maximal specific growth rate obtained by the author $(0.0221 / \mathrm{h})$ is lower than that reached in this work $(0.041 \mathrm{1} / \mathrm{h})$.

Cho et al. (2006) reached maximum biomass concentration equal to $10.4 \mathrm{~g} / \mathrm{L}$, maximal extracellular polysaccharide concentration of $3.05 \mathrm{~g} / \mathrm{L}$ and $\mathrm{Y}_{\mathrm{P} / \mathrm{S}}$ equal to 0.13 in 5 days cultivation of Tremella fuciformis in bioreactor. Hwang et al. (2003) obtained $\Delta \mathrm{X}=11 \mathrm{~g} / \mathrm{L}$ after 15 days cultivation and $\Delta \mathrm{P}=3.3 \mathrm{~g} / \mathrm{L}$ after 14 days cultivation of Phellinus linteus at $\mathrm{pH}$ 4.0. Both studies showed superior results than those observed in this study, but using different microorganisms.

In order to better evaluate the influence of initial glucose concentration ( 40 and $50 \mathrm{~g} / \mathrm{L}$ ) and $\mathrm{pH}$ value (3.0 and 4.0) on $\Delta \mathrm{X}$ and $\Delta \mathrm{P}$ a factorial design was done (Table 2 ).

Table 3 shows the effects of the variables $\mathrm{S}_{0}$ and $\mathrm{pH}$ on the mycelial biomass $(\Delta \mathrm{X})$ and the extracellular polysaccharide $(\Delta \mathrm{P})$ formation. According to the results presented in this Table, $\mathrm{S}_{0}$ in the tested range as well as the interaction between $\mathrm{S}_{0}$ and $\mathrm{pH}$, did not present any significant effect on both mycelial biomass and extracellular

Table 1 - Kinetic parameters for $P$. djamor cultivated with 40 and $50 \mathrm{~g} / \mathrm{L}$ initial glucose concentration, $\mathrm{pH} 3.0$ and 4.0, according to $2^{2}$ factorial design.

\begin{tabular}{lcccc}
\hline Kinetic parameters & $40 \mathrm{~g} / \mathrm{L} \mathrm{pH} 3.0$ & $40 \mathrm{~g} / \mathrm{L} \mathrm{pH} 4.0$ & $50 \mathrm{~g} / \mathrm{L} \mathrm{pH} 3.0$ & $50 \mathrm{~g} / \mathrm{L} \mathrm{pH} 4.0$ \\
\hline$\Delta \mathrm{P}(\mathrm{g} / \mathrm{L})$ & 2.110 & 0.760 & 2.530 & 0.560 \\
$\Delta \mathrm{X}(\mathrm{g} / \mathrm{L})$ & 7.110 & 6.990 & 9.880 & 5.730 \\
$\Delta \mathrm{P}_{\mathrm{m}}(\mathrm{g} / \mathrm{L})$ & 1.810 & 0.650 & 2.420 & 0.496 \\
$\Delta \mathrm{X}_{\mathrm{m}}(\mathrm{g} / \mathrm{L})$ & 6.470 & 6.440 & 10.630 & 3.800 \\
$\mathrm{Y}_{\mathrm{P} / \mathrm{S}}$ & 0.072 & 0.025 & 0.058 & 0.020 \\
$\mathrm{Y}_{\mathrm{X} / \mathrm{S}}$ & 0.240 & 0.230 & 0.228 & 0.206 \\
$\mathrm{Q}_{\mathrm{P}}(\mathrm{mg} / \mathrm{L} \cdot \mathrm{h})$ & 9.340 & 2.380 & 5.040 & 1.320 \\
$\mathrm{Q}_{\mathrm{X}}(\mathrm{mg} / \mathrm{L} \cdot \mathrm{h})$ & 31.400 & 21.970 & 19.680 & 13.540 \\
$\mathrm{Q}_{\mathrm{Pmax}}(\mathrm{mg} / \mathrm{L} . \mathrm{h})$ & 11.260 & 2.670 & 5.170 & 1.510 \\
$\mathrm{Q}_{\mathrm{Xmax}}(\mathrm{mg} / \mathrm{L} . \mathrm{h})$ & 32.200 & 22.190 & 20.020 & 15.830 \\
$\mathrm{t}(\mathrm{h})$ & 226 & 318 & 502 & 423 \\
$\mathrm{t}_{\mathrm{mp}}(\mathrm{h})$ & 161 & 242 & 467 & 328 \\
$\mathrm{t}_{\mathrm{mx}}(\mathrm{h})$ & 201 & 290 & 531 & 240 \\
\hline
\end{tabular}


Table 2 - Factorial design $2^{2}$ to study the effect of initial glucose concentration $\left(\mathrm{S}_{0}\right)$ and $\mathrm{pH}$ values on the mycelial biomass $(\Delta \mathrm{X})$ and EPS $(\Delta \mathrm{P})$ concentrations.

\begin{tabular}{lcccc}
\hline Experiments & $\mathrm{S}_{0}(\mathrm{~g} / \mathrm{L})$ & $\mathrm{pH}$ & $\Delta \mathrm{X} \pm \mathrm{sd}^{*}(\mathrm{~g} / \mathrm{L})$ & $\Delta \mathrm{P} \pm \mathrm{sd} *(\mathrm{~g} / \mathrm{L})$ \\
\hline 1 & 40 & 3 & $6.86 \pm 1.5$ & $2.31 \pm 0.4$ \\
2 & 40 & 4 & $6.28 \pm 2.2$ & $0.73 \pm 0.3$ \\
3 & 50 & 3 & $7.86 \pm 2.6$ & $2.15 \pm 0.9$ \\
4 & 50 & 4 & $5.60 \pm 0.3$ & $0.56 \pm 0.02$ \\
\hline
\end{tabular}

*Standard deviation.

Table 3 - Effects of the variables $\mathrm{S}_{0}$ and $\mathrm{pH}$ on the mycelial biomass formation $(\Delta \mathrm{X})$ and maximal extracellular polysaccharide concentration $(\Delta \mathrm{P})$ by the factorial design.

\begin{tabular}{lcc}
\hline Variables & \multicolumn{2}{c}{ Effects } \\
\cline { 2 - 3 } & $\Delta \mathrm{X}\left(\mathrm{g} / \mathrm{L} \pm \mathrm{SE}^{*}\right)$ & $\Delta \mathrm{P}\left(\mathrm{g} / \mathrm{L} \pm \mathrm{SE}^{*}\right)$ \\
\hline $\mathrm{pH}(1)$ & $-1.42 \pm 1.33$ & $-1.58 \pm 0.38^{* *}$ \\
$\mathrm{~S}_{0}(2)$ & $0.16 \pm 1.33$ & $-0.16 \pm 0.38$ \\
$(1)$ and $(2)$ & $-0.83 \pm 1.33$ & $-0.00 \pm 0.38$ \\
\hline
\end{tabular}

*Standard error, **Statistically significance effect ( $95 \%$ confidence limits).

polysaccharide concentration. However, $\mathrm{pH}$ has a negative significant effect on the extracellular polysaccharide formation. The lower $\mathrm{pH}$ value $(\mathrm{pH} 3.0)$ led to a gain of approximately $1.6 \mathrm{~g} / \mathrm{L}$ on extracellular polysaccharide concentration. The highest values of extracellular polysaccharide concentration (Table 2) were obtained using $40 \mathrm{~g} / \mathrm{L}$ initial glucose and $\mathrm{pH} 3.0(2.31 \pm 0.4 \mathrm{~g} / \mathrm{L})$ and $50 \mathrm{~g} / \mathrm{L}$ initial glucose and $\mathrm{pH} 3.0(2.15 \pm 0.9 \mathrm{~g} / \mathrm{L})$.

Wisbeck (2003) evaluated the effect of initial glucose concentration (20 and $40 \mathrm{~g} / \mathrm{L}$ ) and $\mathrm{pH}(4.0$ and 6.0) on extracellular polysaccharide production by Pleurotus ostreatus in submerged culture. The initial glucose concentration of $40 \mathrm{~g} / \mathrm{L}$ and the $\mathrm{pH} 4.0$ maximized the production of extracellular polysaccharides by that microorganism. In this work, using Pleurotus djamor it was observed the same behavior for $\mathrm{pH}$. However, the initial glucose concentration in the tested range had no significant effect on the extracellular polysaccharide formation by the species Pleurotus djamor.

Several kinds of fungi have acidic optima $\mathrm{pH}$ during submerged cultures. Yang and Liau (1998) investigated the effects of environmental parameters on the extracellular polysaccharide production by Ganoderma lucidum in submerged cultures. For the optimal $\mathrm{pH}(4.0-4.5)$ the polysaccharide concentration reached $1.6 \mathrm{~g} / \mathrm{L}$, a value lower than those found in this work at $\mathrm{pH}$ 3.0. Shu and Lung (2004) studied the effects of $\mathrm{pH}$ (3.0-6.0) on extracellular polysaccharide concentration of Antrodia camphorata in a stirred tank fermenter. The optimum $\mathrm{pH}$ for this process was 5.0 , with $0.118 \mathrm{~g} / \mathrm{L}$ of extracellular polysaccharides, a very low value when compared to the finds of this study. Shih et al. (2008) cultivated Grifola frondosa in shake flasks, at different initial $\mathrm{pH}$ (4.0-6.0). After 9 days cultivation, the maximum extracellular polysaccharide concentration $(0.82 \mathrm{~g} / \mathrm{L})$ was obtained in culture grown at an initial $\mathrm{pH}$ 5.0. This value is also lower than the best ones obtained in this investigation.

These results evidence that $P$. djamor is a potential microorganism for extracellular polysaccharide production mainly at $\mathrm{pH} 3.0$ and the initial concentration of glucose $40 \mathrm{~g} / \mathrm{L}$.

\section{Tumor response}

On the 21 th day, mean tumor weight was $6.64 \mathrm{~g}$ in the Untreated Group and $0.37 \mathrm{~g}$ in the Treated Group $(p=0.05)$. Mean tumor volume was $35.3 \mathrm{~cm}^{3}$ in the Untreated Group and $1.6 \mathrm{~cm}^{3}$ in the Treated Group $(\mathrm{p}=0.05)$. A tumor inhibition rate of $94 \%$ was found (Table 4).

Antitumor activity of mushroom extracts have been reported by several authors as described in the review published by Mantovani et al. (2008). Despite $\beta$-glucan polysaccharide has been regarded as the responsible agent for this effect, most of the related studies have used either crude extracts (Lee et al., 2003; Wong et al., 2007; Harhaji et al., 2008) or a fraction of extracts (Ohno et al., 2001; Nakamura et al., 2004; Sarangi et al., 2006; Unursaikhan et al., 2006).

In a detailed biomolecular study, Jedinak and Sliva (2008) analyzed the inhibitory effect of four different mushroom extracts on proliferative activity of breast and colon cancer cell cultures. Pleurotus ostreatus extract was found to present a most potent suppression of both breast and colon cancer cell proliferation, but no effect was observed on normal mammary or colonic cells. $\beta$-glucans are glucose polymers that differ from each other by a highly variable structure of length and branching. Their immune function is apparently related to the conformational complexity and it has been suggested that intensity of anticancer effects is associated to a higher degree of structural complexity (Bohn and BeMiller, 1995).

This is the rational to assess the anti-tumoral effect of different species of $\beta$-glucan containing mushrooms. In the present study, we present the first investigation on the potential anticancer effects of Pleurotus djamor after its isolation.

Table 4 - Weight, volume tumor and inhibition rate for the treated and untreated groups with polysaccharides extract of $P$. djamor.

\begin{tabular}{lccc}
\hline Groups & $\begin{array}{c}\text { Tumor weight } \\
\left.(\mathrm{g} \pm \mathrm{sd})^{*}\right)\end{array}$ & $\begin{array}{c}\text { Tumor volume } \\
\left(\mathrm{cm}^{3} \pm \mathrm{sd}^{*}\right)\end{array}$ & $\begin{array}{c}\text { Inhibition rate } \\
(\%)\end{array}$ \\
\hline Treated & $0.37 \pm 0.07$ & $1.6 \pm 0.15$ & 94 \\
Untreated & $6.64 \pm 1.19$ & $35.37 \pm 12.16$ & - \\
\hline
\end{tabular}

*Standard deviation. 
The impressive results obtained in this pilot study suggests an inhibitory effect of $P$.djamor extract on cancer cells and have encourage us to pursued in further efforts to assess its role in future benefits in the treatment of malignant diseases.

\section{Acknowledgments}

The group wishes to thank the Research and Support Fund - FAP from UNIVILLE for the financial backing for the project. The authors wish to express their gratitude to Dr. A. A. Steil and Dr. D. Sato, from UNIVALI, for donating the tumor strain.

\section{Nomenclature}

a - The short diameter $\left(\mathrm{mm}^{2}\right)$

$\mathrm{b}$ - The long diameter $\left(\mathrm{mm}^{2}\right)$

$\mathrm{C}$ and $\mathrm{T}$ - The tumor weight of the untreated group and the treated group, respectively

$\mathrm{K}_{\mathrm{L}} \mathrm{a}$ - volumetric oxygen transfer rate

$\mathrm{Q}_{\mathrm{P}}, \mathrm{Q}_{\mathrm{X}}$ - global productivities in extracellular polysaccharides and biomass (for $\mathrm{t}=\mathrm{t}$ )

$\mathrm{Q}_{\mathrm{Pmax}}, \mathrm{Q}_{\mathrm{X} \max }$ - maximum productivities in extracellular polysaccharides (for $\mathrm{t}=\mathrm{t}_{\mathrm{mp}}$ ) and biomass (for $\mathrm{t}=\mathrm{t}_{\mathrm{mx}}$ )

$\mathrm{P}, \mathrm{S}, \mathrm{X}$ - Product, substrate and biomass concentrations

$\Delta \mathrm{P}, \Delta \mathrm{X}$ - extracellular polysaccharides and biomass formed until the stabilization of extracellular polysaccharide concentration at its maximum value

$\Delta \mathrm{P}_{\mathrm{m}}$ - extracellular polysaccharide concentration formed by the time that productivity in extracellular polysaccharides is maximal

$\Delta \mathrm{X}_{\mathrm{m}}$ - mycelial biomass concentration formed by the time that productivity in biomass is maximal

$\mathrm{t}$ - time process, considered the time of the stabilization of extracellular polysaccharide concentration at its maximum value

$t_{m p}$ - time for $Q_{P \max }$

$\mathrm{t}_{\mathrm{mx}}$ - time for $\mathrm{QX}_{\mathrm{Xmax}}$

$\mathrm{Y}_{\mathrm{P} / \mathrm{S}}, \mathrm{Y}_{\mathrm{X} / \mathrm{S}}$ - global yield factors of extracellular polysaccharides on substrate and biomass on substrate $($ for $\mathrm{t}=\mathrm{t}$ )

\section{References}

Ajith TA, Janardhanan KK (2003) Cytotoxic and antitumor activities of a polypore macrofungus, Phellinus rimosus (Berk) Pilat. J Ethnopharmacol 84:157-162.

Barros Neto B, Scarminio IS, Bruns RE (1996) Planejamento e otimização de experimentos. Editora Unicamp, Campinas, Brazil.

Bonatti M, Libardi Junior N, Borges GM, Wisbeck E, Furlan SA (2008) Produção de polissacarídeos extracelulares provenientes de Pleurotus ostreatus por processo semicontínuo. XVII Congresso Brasileiro de Engenharia Química, Recife, PE, p. 1-7.

Bohn JA, BeMiller JN (1995) (1-3)- $\beta$-Glucans as biological response modifiers: a review of structure-functional activity relationships. Carbohydr Polym 28:3-14.
Cavazzoni V, Adami A (1992) Exopolysaccharides produced by mycelial edible mushrooms. Ital J Food Sci 1:9-15.

Cho EJ, Oh JY, Chang HY, Yun JW (2006) Production of exopolysaccharides by submerged mycelia culture of a mushroom Tremella fuciformis. J Biotechnol 127:129-140.

Dalonso N, Souza R, Silveira MLL, Ruzza AA, Wagner TM, Wisbeck E, Furlan, SA (2010) Characterization and antineoplasic effect of extracts obtained from Pleurotus sajor-caju fruiting bodies. Appl Biochem Biotechnol 160:2265-2274.

Dubois M, Gilles KA, Hamilton JK, Rebers PA, Smith F (1956) Colorimetric method for determination of sugars and related substances. Anal Chem 28:350-356.

Firenzuoli F, Gori L, Lombardo G (2008) The medicinal mushroom Agaricus blazei Murrill: review of literature and pharmaco-toxicological problems. eCAM 5:3-15.

Furlan SA, Gern RMM, Wisbeck E, Bonatti M, Silveira MLL, Silva HH (2008) Possibilities of Pleurotus applications in food, health and environmental technologies. In: Koutinas, A., Pandey, A., Larroche, C. (eds). Current Topics on Bioprocesses in Food Industry. Asiatech Publishers Inc, New Delhi, Indian, 482-495.

Furlan SA, Silveira MLL, Wisbeck E, Wolff ERS, Dalonso N, Ruzza AA, Pinho MSL (2009) Antitumor activity of Pleurotus spp. In: Pandey, A., Larroche, C., Soccol, C.R., Dussap, C.G. (eds). New Horizons in Biotechnology. Asiatech Publishers Inc, New Delhi, Indian, 429-439.

Furlan SA, Virmond LJ, Miers DA, Bonatti M, Gern RM, Jonas R (1997) Mushrooms strains able to grow at high temperatures and low pH values. World $J$ Microbiol Biotechnol 13:689692.

Gern RMM, Wisbeck E, Rampinelli JR, Ninow JL, Furlan SA (2008) Alternative medium for production of Pleurotus ostreatus biomass and potential antitumor polysaccharides. Biores Technol 99:76-82.

Gu YH, Sivam G (2006) Cytotoxic effect of oyster mushroom Pleurotus ostreatus on human androgen-independent prostate cancer PC-3 cells. J Med Food 9:196-204.

Harhaji L, Mijatovic S, Maksimovic-Ivanic D, Stojanovic I, Momcilovic M, Maksimovic V, Tufegdzic S, Marjanovic Z, Mostarica-Stojkovic M, Vucinic Z, Stosic-Grujicic S (2008) Anti-tumor effect of Coriolus versicolor methanol extract against mouse B16 melanoma cells: in vitro and in vivo study. Food Chem Toxicol 46:1825-1833.

Hwang HJ, Kim SW, Choi JW, Yun JW (2003) Production and characterization of exopolysaccharides from submerged culture of Phellinus linteus KCTC 6190. Enz Microbial Technol 33:309-319.

Jedinak A, Sliva D (2008) Pleurotus ostreatus inhibits proliferation of human breast and colon cancer cells through p53dependent as well as p53-independent pathway. Int J Oncol 33:1307-1313.

Lavi I, Friesem D, Geresh S, Hadar Y, Schwartz B (2006) An aqueous polysaccharide extract from the edible mushroom Pleurotus ostreatus induces anti-proliferative and pro-apoptotic on HT-29 colon cancer-cells. Cancer Lett 244:61-70.

Lee YL, Kim HJ, Lee MS, Kim JM, Han JS, Hong EK, Kwon MS, Lee MJ (2003) Oral administration of Agaricus blazei (H1 strain) inhibited tumor growth in a sarcoma 180 inoculation model. Exp Anim 52:371-375. 
Mantovani MS, Bellini MF, Angeli JPF, Oliveira RJ, Silva AF, Ribeiro LR (2008) $\beta$-Glucan in promoting health: prevention against mutation and cancer. Mutat Res 658:154-161.

Misaki A, Kawaguchi K, Miyaji H, Nagae H, Hokkoku S, Kakuta M, Sasaki T (1984) Structure of pestalotan, a highly branched (1-3)- $\beta$-D-glucan elaborated by Pestalotia sp. 815, and the enhancement of its antitumor activity by polyol modification of the side chains. Carbohydr Res 129:209227.

Mizuno M, Minato K, Ito H, Kawade M, Terai H, Tsuchida H (1999) Anti-tumor polysaccharide from the mycelium of liquid-cultured Agaricus blazei mill. Biochem Mol Biol Int 47:707-714.

Nakamura T, Matsugo S, Uzuka Y, Matsuo S, Kawagishi H (2004) Fractionation and anti-tumor activity of the mycelia of liquid-cultured Phellinus linteu. Biosci Biotechnol Biochem 68:868-872.

Ohno N, Furukawa M, Miura NN, Adachi Y, Motoi M, Yadomae $\mathrm{T}$ (2001) Antitumor $\beta$-glucan from the cultured fruit body of Agaricus blazei. Biol Pharm Bull 24:820-828.

Pagno T, Blind LZ, Biavatti MW, Kreuger MR (2006) Cytotoxic activity of the dichloromethane fraction from Vernonia scorpioides (Lam.) Pers. (Asteraceae) against Ehrlich's tumor cells in mice. Braz J Med Biol Res 39:1483-1491.

Pokhrel CP, Ohga S (2007) Submerged culture conditions for mycelial yield and polysaccharides production by Lyophyllum decastes. Food Chem 105:641-646.

Rosado FR, Germano S, Carbonero ER, Costa SMG, Iacomini M, Kemmelmeier C (2003) Biomass and exopolysaccharide production in submerged cultures of Pleurotus ostreatoroseus SING. and Pleurotus ostreatus "florida" (JACK.: FR.) KUMMER. J Basic Microbiol 43:230-237.

Sarangi I, Ghosh D, Bhutia SK, Mallick SK, Maiti TK (2006) Anti-tumor and immunomodulating effects of Pleurotus ostreatus mycelia-derived proteoglycans. Int Immunopharmacol 6:1287-1297.

Shih IL, Chou BW, Chen CC, Wu JY, Hsieh C (2008) Study of mycelial growth and bioactive polysaccharide production in batch and fed-batch culture of Grifola frondosa. Biores Technol 99:785-793.

Shih IL, Pan K, Hsieh C (2006) Influence of nutritional components and oxygen supply on the mycelia growth and bioactive metabolites production in submerged culture of Antrodia cinnamomea. Process Biochem 41:1129-1135.

Shu CH, Lung MY (2004) Effect of $\mathrm{pH}$ on the production and molecular weight distribution of exopolysaccharide by Antrodia camphorata in batch cultures. Process Biochem 39:931-937.

Unursaikhan S, Xu X, Zeng F, Zhang L (2006) Antitumor activities of O-sulfonated derivatives of (1-3)- $\alpha$-D-glucan from different Lentinus edodes. Biosci Biotechnol Biochem 70:38-46.

Wisbeck E (2003) Estudo do cultivo submerso de Pleurotus ostreatus DSM 1833 para a produção de biomassa e de exopolissacarídeos. Florianópolis, Brasil, 175p. (Dr. Thesis. Universidade Federal de Santa Catarina. UFSC).

Wolff ERS, Wisbeck E, Silveira MLL, Gern RMM, Pinho MSL, Furlan SA (2008) Antimicrobial and Antineoplasic Activity of Pleurotus ostreatus. Appl Biochem Biotechnol 151:402412.

Wong SM, Wong KK, Chiu LCM, Cheung PCK (2007) Nonstarch polysaccharides from different developmental stages of Pleurotus tuber-regium inhibited the growth of human acute promyelocytic leukemia HL-60 cells by cell-cycle arrest and/or apoptotic induction. Carbohydr Polym 68:206217.

Yang FC, Liau CB (1998) The influence of environmental conditions on polysaccharide formation by Ganoderma lucidum in submerged cultures. Process Biochem 33:547-553.

Zhang M, Zhang L, Cheung PCK, Ooi VEC (2004) Molecular weight and anti-tumor activity of the water-soluble polysaccharides isolated by hot water and ultrasonic treatment from the sclerotia and mycelia of Pleurotus tuber-regium. Carbohydr Polym 56:123-128.

All the content of the journal, except where otherwise noted, is licensed under a Creative Commons License CC BY-NC. 